\title{
SIMULATION OF PHOTOVOLTAIC SYSTEM CONNECTED WITH FULL BRIDGE INVERTER USING MATLAB / SIMULINK
}

\author{
Anwarul M Haque ${ }^{1}$, Swati Sharma ${ }^{2}$, Devendra Nagal $^{3}$ \\ ${ }^{1}$ Assistant Professor, Power Electronics Department, Vishwakarma Government Engineering College, Chandkheda, \\ Ahmedabad, Gujarat, India \\ ${ }^{2}$ Associate Professor, Electrical Engineering Department, Jodhpur National University, Jodhpur, Rajasthan, India \\ ${ }^{3}$ Assistant Professor, Electrical Engineering Department, Jodhpur National University, Jodhpur, Rajasthan, India
}

\begin{abstract}
When sunlight shines on a PV cell, the absorbed light produces electricity. Though PV technologies use both direct and dispersed sunlight to create electricity, harnessing efficiency is $68 \%$ eventually against the claim of $85 \%$ by the various manufacturers worldwide. Power Electronics Interface are incorporated with Photovoltaic (PV) System to intensify the efficiency of the PV system and undoubtedly we have reached to the goalmouth. There are two stages where power electronics converter are used. First DC-DC converter stage in which lower level PV voltage is boosted-up at the required higher level; and second DC-AC inverter stage in which increased DC link voltage is efficiently converted into AC. Purpose of this paper is to elaborate the FullBridge inverter used in PV System and switching schemes adopted for the operation and to realize the best switching scheme. Simulation results are taken at various stages to visualize the effect of interface. For whole PV system simulation, PV module is connected to the converter system. The output of the Buck Boost converter is connected to the single-phase inverter and the inverter output is fed to the AC grid.
\end{abstract}

Key Words: H-Bridge Inverter, Switching Scheme, PV module, Converter, Simulink block-sets.

\section{INTRODUCTION}

For developing countries, providing energy to its stakeholders in an efficient and cost effective manner is a highly challenging task. In spite of significant harnessing of the fossil fuel reserves, the breach between supply and demand of energy is ever growing. One of the possible options to tie this breach is by making extensive use of solar power [4].

The need for a clean surroundings and the incessant increase in energy demand makes decentralized renewable energy production more and more substantial [4]. Photovoltaic generate electric power when illuminated by sunlight or artificial light. It directly convert the sun's energy into electricity which can be easily transported and converted to other forms for the benefit of society [16].

Though PV technologies use both direct and dispersed sunlight to create electricity, harnessing efficiency is $68 \%$ eventually against the claim of $85 \%$ by the various manufacturers worldwide. Power Electronics Interface are incorporated with PV System to intensify the efficiency of the PV system and undoubtedly we have reached to the goalmouth.

Power Electronics is the field of engineering which deals with the use of electronics for the conversion, control and conditioning of bulk electrical power. It also plays an important role in the solar system [11], [12], [13], [15]. There are two stage where power electronics converter are used. First DC-DC converter stage in which lower level PV voltage is stepped-up at the required higher level [24]; and second DC-AC inverter stage in which boosted DC link voltage is converted into AC [17], [18]. If Maximum Power
Point Tracking (MPPT) is accountable for optimizing the efficiency of the photovoltaic system, power electronics interface is the solver. The power loses incurred at the converter stage is reimbursed at inverter stage. This proposed PV module gives the maximum power, voltage and current independent of the load.

\section{DC-AC INVERTER STAGE}

The power produced by a PV module is in the form of direct current. Conversion of direct current to alternating current required by many common appliances and for gridconnection is realized with an inverter. Inverter is basically an interface between photovoltaic cell and AC grids. There are several inverter topologies but output current distortion and efficiency are the two key parameters for the selection of inverters. Power inverters produce one of three different types of wave output [1] [2] [3] [4].

- Square Wave

- Modified Sine Wave

- Pure Sine Wave

Based on their operation the inverters can be broadly classified into

- Voltage source inverter (VSI)

- Current source inverter (CSI)

The output voltage waveform of Voltage Source Inverter are independently controlled and mostly remain unaffected by the load. Due to this phenomenal behavior, the VSI have many industrial applications such as adjustable speed drives and also in Power system for FACTS (Flexible AC 
Transmission System) [21]. The voltage source inverter possesses a capacitor in parallel with the DC input [2], [5].

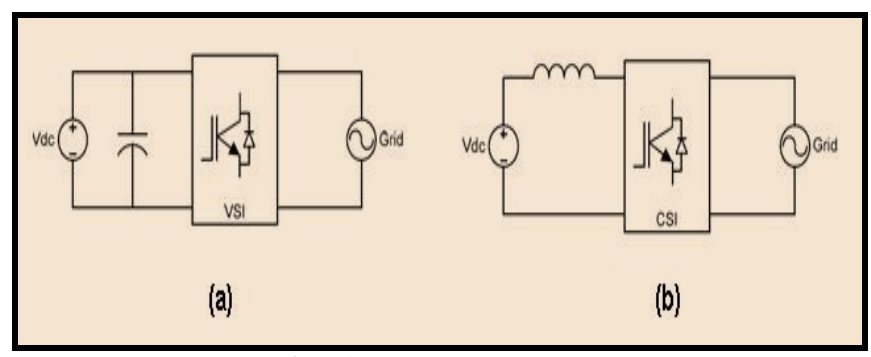

Fig -1: VSI (a), CSI (b)

The output current waveform of Current Source Inverter are independently controlled and mostly remain unaffected by the load. Such Inverters are broadly used in medium voltage industrial applications where high quality waveform is mandatory. The current source inverters possess an inductor in series with the input. The converter topology are shown in Fig 1(a) and (b). Full - Bridge inverters are widely used in Photovoltaic system [26]. Therefore here we will discuss the full bridge voltage source inverter and its switching schemes.

\subsection{Full Bridge Inverter}

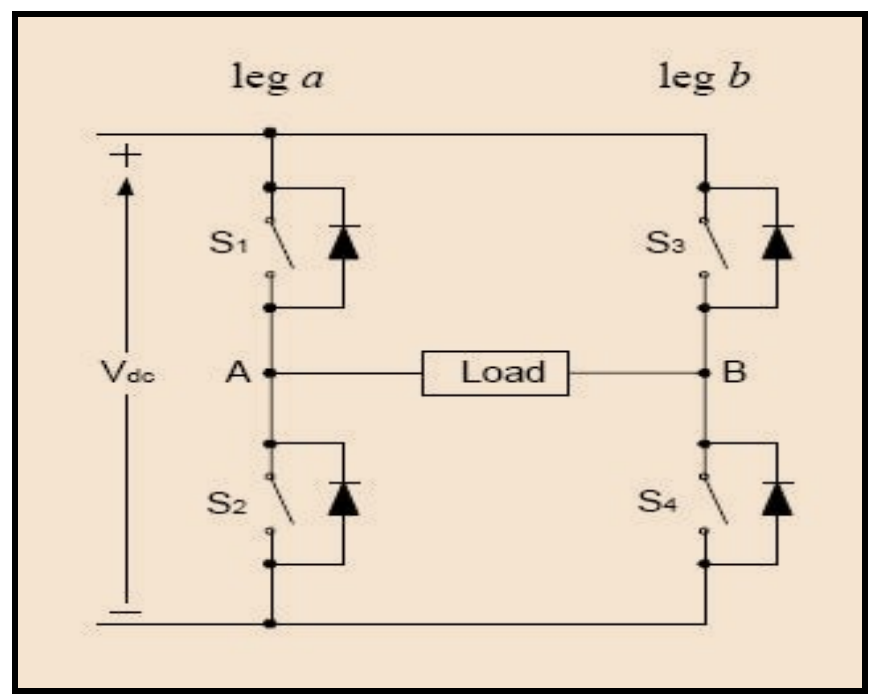

Fig -2: Full - Bridge Inverter

Fig 2 the Full bridge inverter consists of two parallel strings contributing two switching power devices in series with anti-paralleled diodes. Variation of duty cycle of the PWM signal offers a voltages across the load in a specific pattern which appear to the load as AC signal. A pure sin wave is attained after passing the signal through a low pass filter [25]. The pattern at which the duty cycle of a PWM signal varies can be realized using simple analogue components or a digital microcontroller [20]. Either of the two basic topologies generate sinusoidal PWM that controls the output of the inverter [1]. The full bridge converter can be used to generate two different PWM pulse trains depending on the switching scheme implemented. The two schemes are called bipolar and unipolar switching [6], [7], [13], [15], [22].

\subsubsection{Bipolar Switching Scheme}

A full bridge converter which uses a bipolar switching scheme is called a two level converter.

Table -1: switching states for bipolar switching scheme for a full bridge converter

\begin{tabular}{c|c|c|c|}
$\begin{array}{c}\text { Switching } \\
\text { State }\end{array}$ & $\begin{array}{c}\text { Switches } \\
\text { On }\end{array}$ & $\begin{array}{c}\text { Switches } \\
\text { Off }\end{array}$ & $\begin{array}{c}\text { Pulsed } \\
\text { Output } \\
\text { Voltage } \\
\left(\mathrm{V}_{\mathrm{j}}\right)\end{array}$ \\
\hline 1 & $\mathrm{~S}_{1}, \mathrm{~S}_{4}$ & $\mathrm{~S}_{2}, \mathrm{~S}_{3}$ & $+\mathrm{V}_{\mathrm{dc}}$ \\
\hline 2 & $\mathrm{~S}_{2}, \mathrm{~S}_{3}$ & $\mathrm{~S}_{1}, \mathrm{~S}_{4}$ & $-\mathrm{V}_{\mathrm{dc}}$ \\
\hline
\end{tabular}

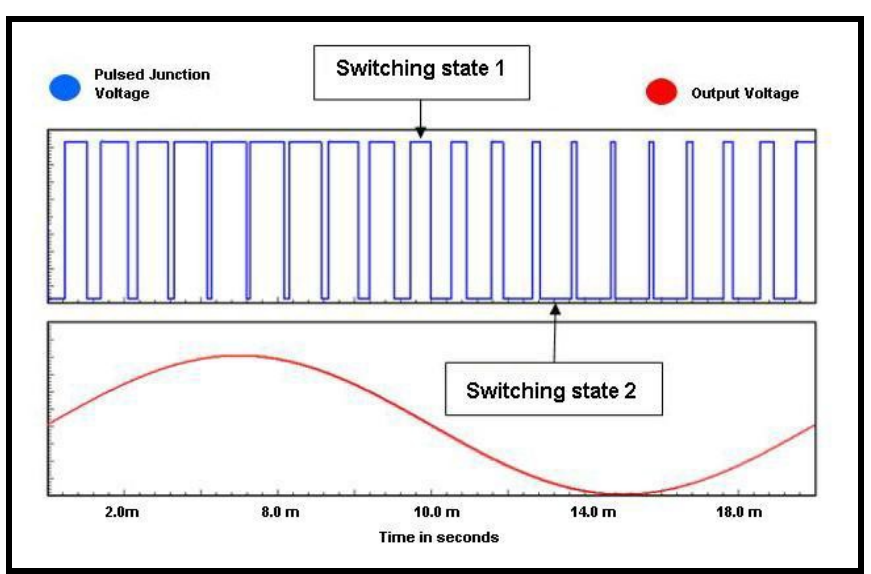

Fig - 3: Bipolar (Two Level) Switching Scheme

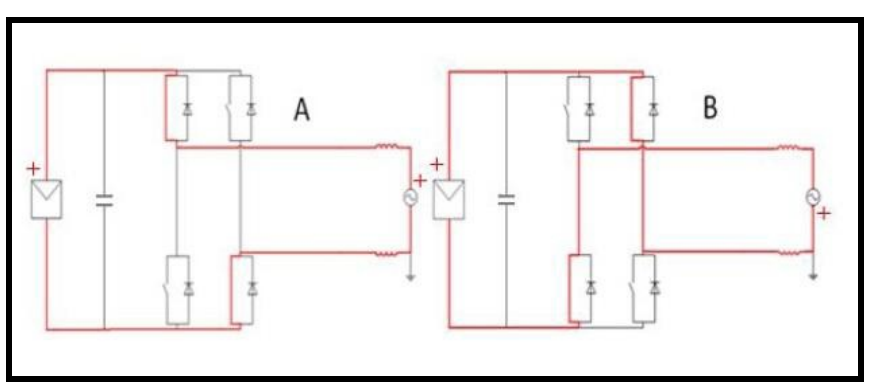

Fig - 4: A - Current Path for Full Bridge Converter implementing Bipolar Switching Scheme during Switching State -1, B - Current Path for Full Bridge Converter implementing Bipolar Switching Scheme during Switching State-2

With a bipolar switching scheme, the full bridge converter only has two switching states as the junction voltage $\left(\mathrm{V}_{\mathrm{j}}\right)$ switches from $+\mathrm{V}_{\mathrm{dc}}$ to $-\mathrm{V}_{\mathrm{dc}}$ using PWM. When used as a two level converter the full bridge converter uses the switching scheme outlined in Table I the resulting pulsed output is displayed in Fig 3. Figure 4 displays the carrying current paths at each switching state [6]. 


\subsubsection{Unipolar Switching Scheme}

A full bridge converter which uses unipolar switching is called a three level converter. A unipolar switching scheme is where the output of the converter $\left(\mathrm{V}_{\mathrm{j}}\right)$ switches between $+\mathrm{V}_{\mathrm{dc}}$ and zero during the positive half wave and between and $-V_{\mathrm{dc}}$ and zero during the negative half wave.

Table -2: Switching States for Standard Unipolar Switching Scheme for a Full Bridge Converter

\begin{tabular}{|c|c|c|c|c|}
\hline $\begin{array}{c}\text { Switching } \\
\text { state }\end{array}$ & $\begin{array}{c}\text { Switch } \\
\text { on }\end{array}$ & $\begin{array}{c}\text { Switch } \\
\text { off }\end{array}$ & $\begin{array}{c}\text { Junction } \\
\text { voltage }\end{array}$ & $\begin{array}{c}\text { Half } \\
\text { wave }\end{array}$ \\
\hline 1 & $\mathrm{~S}_{1}, \mathrm{~S}_{4}$ & $\mathrm{~S}_{2}, \mathrm{~S}_{3}$ & $+\mathrm{V}_{\mathrm{dc}}$ & Positive \\
\hline 2 & $\mathrm{~S}_{1}, \mathrm{~S}_{3}$ & $\mathrm{~S}_{1}, \mathrm{~S}_{4}$ & 0 & Positive \\
\hline 3 & $\mathrm{~S}_{1}, \mathrm{~S}_{4}$ & $\mathrm{~S}_{2}, \mathrm{~S}_{3}$ & $-\mathrm{V}_{\mathrm{dc}}$ & Positive \\
\hline 4 & $\mathrm{~S}_{2}, \mathrm{~S}_{4}$ & $\mathrm{~S}_{1}, \mathrm{~S}_{3}$ & 0 & Positive \\
\hline 5 & $\mathrm{~S}_{2}, \mathrm{~S}_{3}$ & $\mathrm{~S}_{1}, \mathrm{~S}_{4}$ & $+\mathrm{V}_{\mathrm{dc}}$ & Negative \\
\hline 6 & $\mathrm{~S}_{1}, \mathrm{~S}_{3}$ & $\mathrm{~S}_{2}, \mathrm{~S}_{4}$ & 0 & Negative \\
\hline 7 & $\mathrm{~S}_{2}, \mathrm{~S}_{3}$ & $\mathrm{~S}_{1}, \mathrm{~S}_{4}$ & $-\mathrm{V}_{\mathrm{dc}}$ & Negative \\
\hline 8 & $\mathrm{~S}_{2}, \mathrm{~S}_{4}$ & $\mathrm{~S}_{1}, \mathrm{~S}_{3}$ & 0 & Negative \\
\hline
\end{tabular}

Table - 3: Switching States for One Phase Chopping Unipolar Switching Scheme (type -a) for a full bridge converter

\begin{tabular}{|c|c|c|c|}
\hline $\begin{array}{c}\text { Switching } \\
\text { state }\end{array}$ & Switch on & $\begin{array}{c}\text { Switch } \\
\text { off }\end{array}$ & $\begin{array}{c}\text { Junction } \\
\text { voltage }\end{array}$ \\
\hline 1 & $\mathrm{~S}_{1}, \mathrm{~S}_{4}$ & $\mathrm{~S}_{2}, \mathrm{~S}_{3}$ & $+\mathrm{V}_{\mathrm{dc}}$ \\
\hline 2 & $\mathrm{~S}_{2}, \mathrm{~S}_{4}$ & $\mathrm{~S}_{1}, \mathrm{~S}_{3}$ & 0 \\
\hline 3 & $\mathrm{~S}_{2}, \mathrm{~S}_{3}$ & $\mathrm{~S}_{1}, \mathrm{~S}_{4}$ & $-\mathrm{V}_{\mathrm{dc}}$ \\
\hline 4 & $\mathrm{~S}_{2}, \mathrm{~S}_{4}$ & $\mathrm{~S}_{1}, \mathrm{~S}_{3}$ & 0 \\
\hline
\end{tabular}

Unlike bipolar switching, unipolar switching requires at least three different switching states as the junction voltage $\left(\mathrm{V}_{\mathrm{j}}\right)$ can be either $+\mathrm{V}_{\mathrm{dc}},-\mathrm{V}_{\mathrm{dc}}$ or zero although most inverters implement four switching states by having a different switching combination to create the zero junction voltage for each half wave. This to evenly distribute the use of switches making heating symmetrical and thereby reducing losses [6], [19].

A number of different unipolar switching schemes exist for full bridge topologies with associated advantages and disadvantages regarding PV array voltage, switching losses and complexity of control signal generation [23].
The three unipolar switching schemes implemented by full bridge topologies that schemes and associated switching states and orders are presented in Table $2,3 \& 4$.

Table - 4: Switching States for One Phase Chopping Unipolar Switching Scheme for a Full Bridge Converter (Type b)

\begin{tabular}{|c|c|c|c|}
\hline $\begin{array}{c}\text { Switching } \\
\text { state }\end{array}$ & $\begin{array}{c}\text { Switch } \\
\text { on }\end{array}$ & $\begin{array}{c}\text { Switch } \\
\text { off }\end{array}$ & $\begin{array}{r}\text { Junction } \\
\text { voltage }\end{array}$ \\
\hline 1 & $\mathrm{~S}_{1}, \mathrm{~S}_{4}$ & $\mathrm{~S}_{2}, \mathrm{~S}_{3}$ & $+\mathrm{V}_{\mathrm{dc}}$ \\
\hline 2 & $\mathrm{~S}_{2}, \mathrm{~S}_{4}$ & $\mathrm{~S}_{1}, \mathrm{~S}_{3}$ & 0 \\
\hline 3 & $\mathrm{~S}_{2}, \mathrm{~S}_{3}$ & $\mathrm{~S}_{1}, \mathrm{~S}_{4}$ & $-\mathrm{V}_{\mathrm{dc}}$ \\
\hline 4 & $\mathrm{~S}_{3}, \mathrm{~S}_{1}$ & $\mathrm{~S}_{2}, \mathrm{~S}_{4}$ & 0 \\
\hline
\end{tabular}

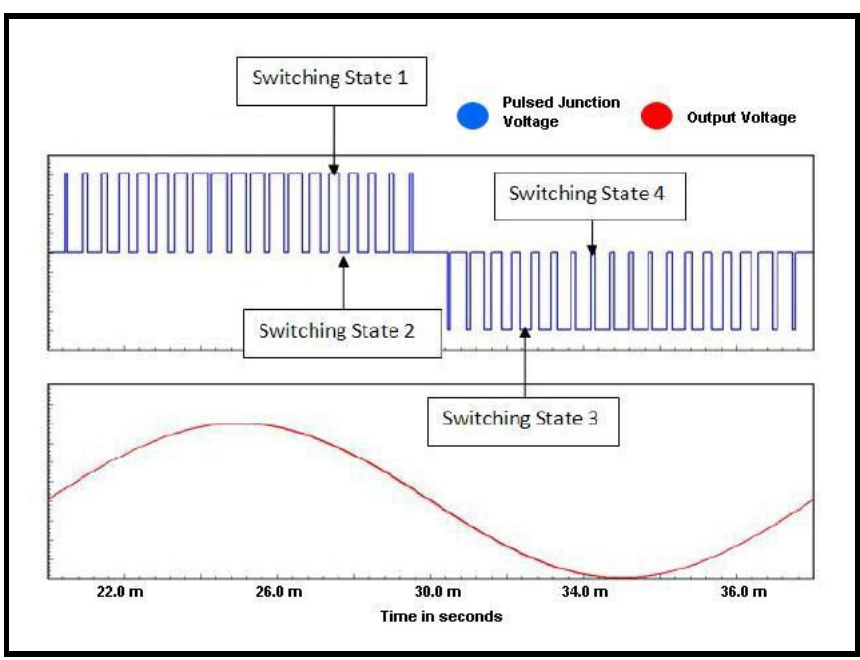

Fig - 5: Unipolar (Four Level) Switching Scheme

The main difference between the three presented unipolar switching schemes is the implementation of different freewheeling states during each half wave. While both one phase chopping methods operate similarly with the only difference being that type $\mathrm{B}$ implements a different switching state for the freewheeling state of each half wave, the standard method is subtly different because both freewheeling states occur in the same half wave [6].

The resulting pulsed output of the one phase chopping scheme (type B) is displayed in Fig 5. The associated current paths are displayed in Fig 6 [6].

One of the main advantage of executing a unipolar switching scheme compared to a bipolar scheme is that the switching losses are significantly reduced due to the allied voltage drop of switching from one state to another.

One drawback of executing a unipolar switching scheme is that, there are higher associated harmonic content in the output current round the zero crossing (particularly at lower power levels). 


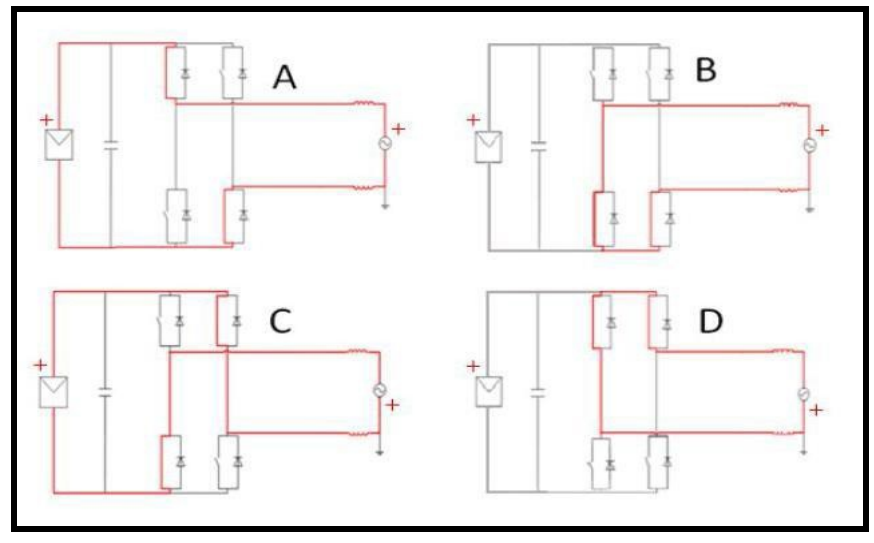

Fig - 6: A-Current Path for Full Bridge Converter implementing Unipolar Switching Scheme B-Current Path for Full Bridge Converter implementing Unipolar Switching Scheme during Switching State 2, C-Current Path for Full Bridge Converter implementing Unipolar Switching Scheme during Switching State 3 D- Current Path for Full Bridge Converter implementing Unipolar Switching Scheme during Switching State 4.

\section{SIMULATION OF PV CONNECTED TO THE}

\section{SINGLE PHASE FULL BRIDGE INVERTER}

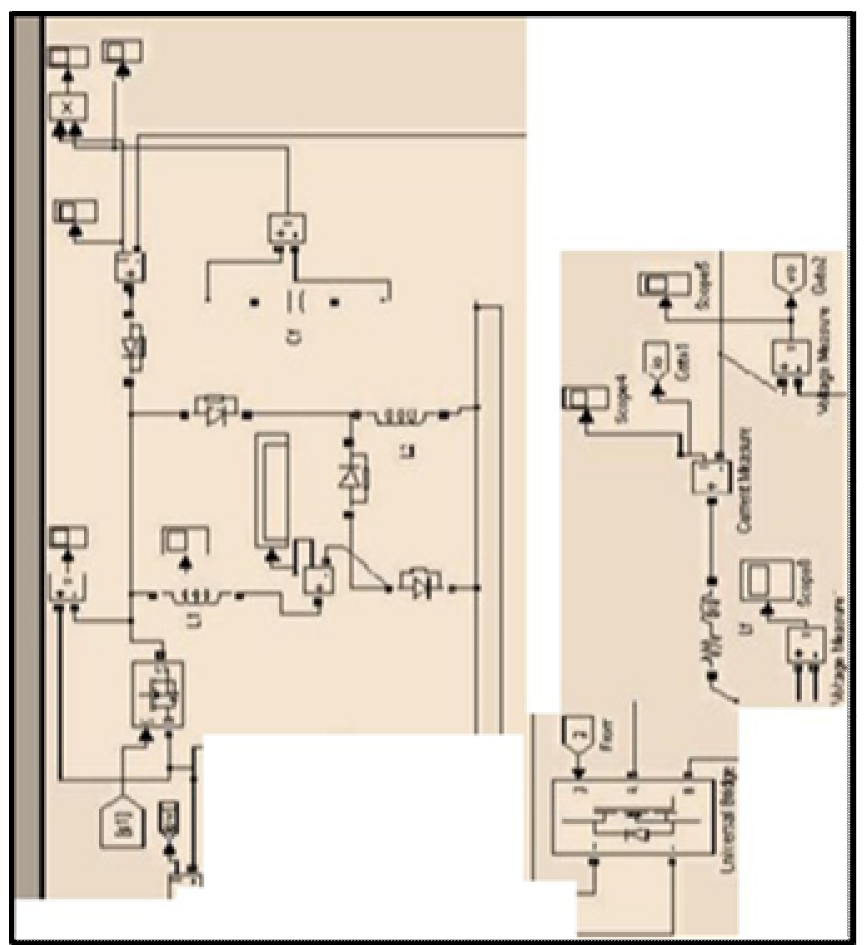

Fig - 7: Simulink model of PV System connected to the single phase Full Bridge Inverter

Fig 7 shows the PV system simulation. The output of the Buck Boost converter is connected to the single-phase inverter and the inverter output is fed to the AC grid. The simulation of the single phase photovoltaic system is realized by adding a single phase full bridge inverter from the Simulink block toolbox.
The Simulink block diagram of the current control loop is shown in Fig 8. First of all an external voltage signal corresponding to the grid voltage is fed into a discrete single- phase phase-locked-loop (PLL). The gain at the input of PLL is recycled to normalize the actual voltage signal. The output of the PLL block produces a reference sin wave. This Sine wave together with the gain block is used to create the reference current.

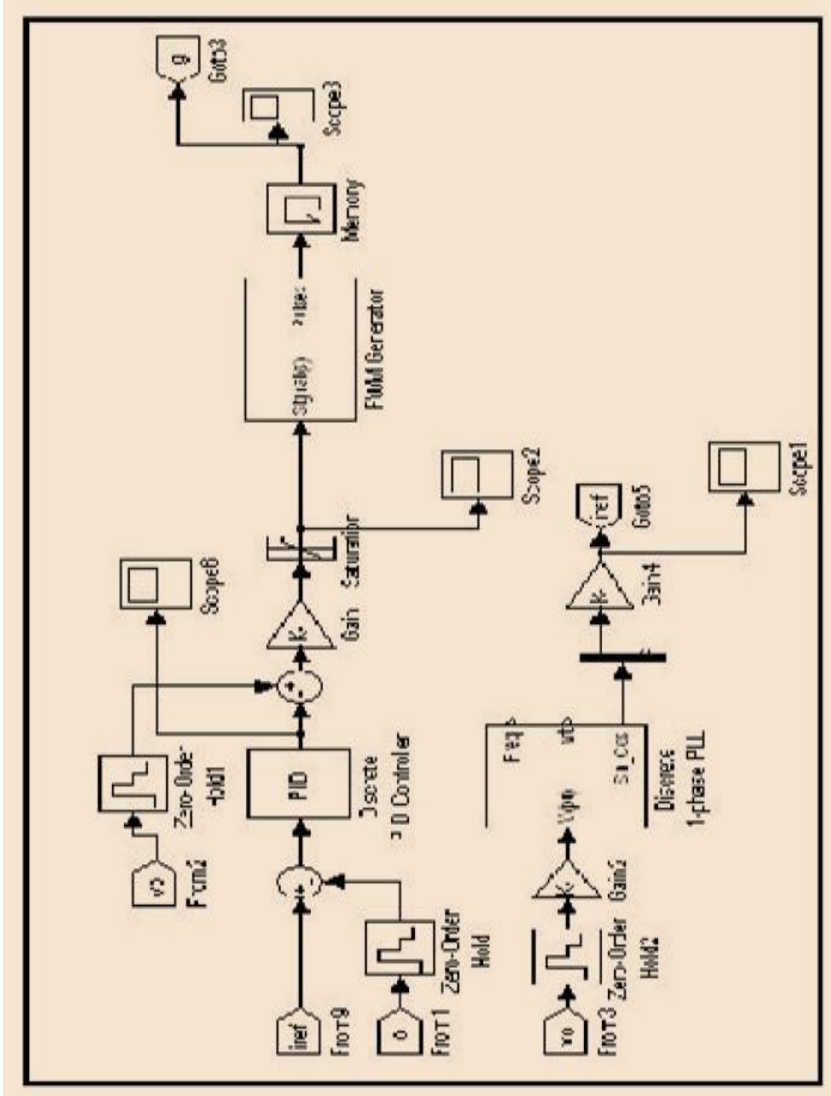

Fig - 8: Simulink model of the grid current control scheme

Current measured from the inverter output and created reference current is compared and the error from the output of comparator is given to the discrete PID controller. Here proportional gain taken is $\mathrm{K}_{\mathrm{p}}=100$, Integral $\mathrm{K}_{\mathrm{i}}=200$, and derivative gain $\mathrm{K}_{\mathrm{d}}=0$. Controller output is added with ac voltage feed forward from the inverter. This output is the reference grid voltage, which separated by the DC source voltage with the use of gain block, it also provides the duty cycle for the inverter.

Table - 5: Simulation Parameter for Converter

\begin{tabular}{|l|l|}
\hline Description & Rating \\
\hline Inductor & $85 \mu \mathrm{H}$ \\
\hline Capacitor & $300 \mu \mathrm{F}$ \\
\hline Resistive Load & $100 \Omega$ \\
\hline Switching Frequency & $10 \mathrm{KHz}$ \\
\hline
\end{tabular}

Saturation block is used to ensure the controlled signal do not saturate. This saturated signal is given to the pulse generator which provides the gate pulses for the Inverter 
switch. Simulation results are illustrated from Fig 9 to Fig 18. FFT analysis of the output current of inverter for one cycle and three cycles are also displayed in Fig 19 \& Fig 20. Here PV system simulation results are observed for PV module BP 3170 and switched inductor buck-boost converter parameters mentioned in Table 5 .

\subsection{Simulation Results}

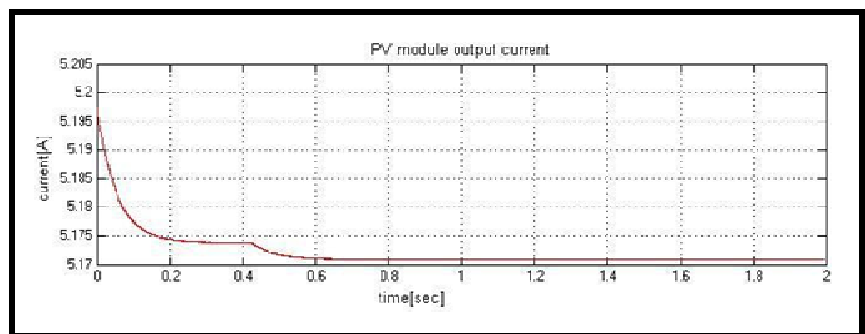

Fig - 9: PV module output current

Fig 9 shows the output current from the photovoltaic module. From this result we can see that photovoltaic current is gradually decreases from short circuit current $5.2 \mathrm{~A}$ to the $5.17 \mathrm{~A}$ and after this it remain constant.

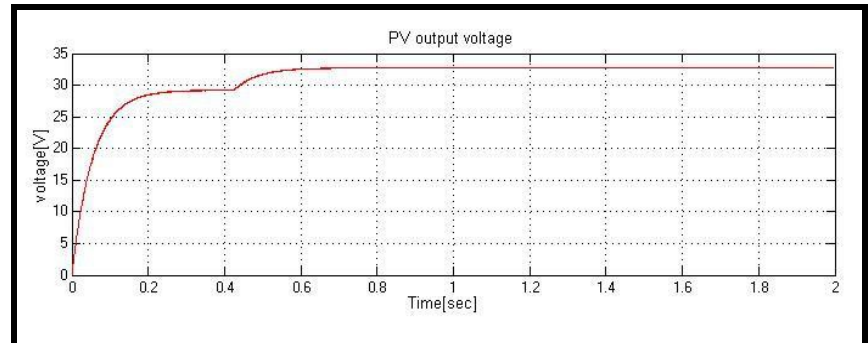

Fig - 10: PV module output voltage

Fig 10 shows the output voltage from the photovoltaic module. From this result we can see that photovoltaic voltage increases from zero to 32.8 volt. After this it remains constant.

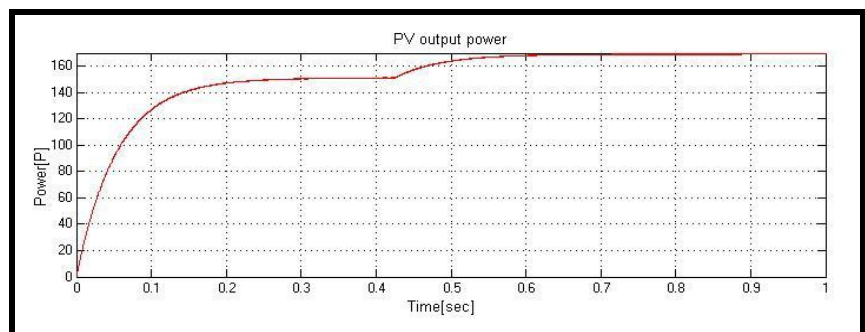

Fig - 11: PV module output power

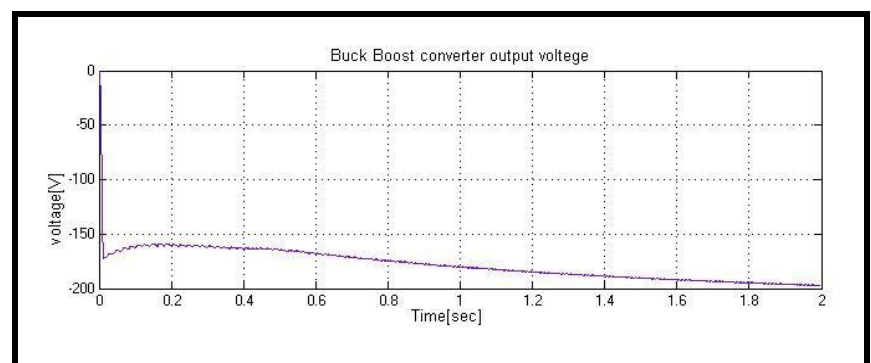

Fig - 12: Buck boost converter output voltage
Fig 11 shows the output power from the photovoltaic module. Maximum power output from the photovoltaic module is $169.5 \mathrm{~W}$ which is almost equal to $\mathrm{P}_{\text {mpp }}$ given into the data sheet of the photovoltaic module.

Fig 12 shows the buck boost converter output voltage. Input voltage from the photovoltaic module 32.8 is boosted up to 200 volt.

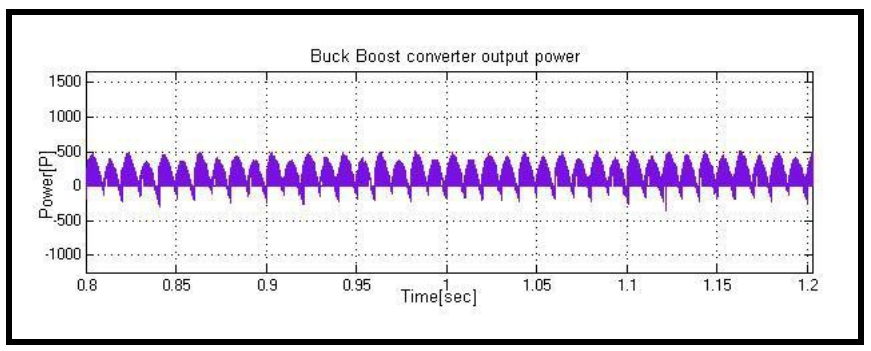

Fig - 13: Buck boost converter output power

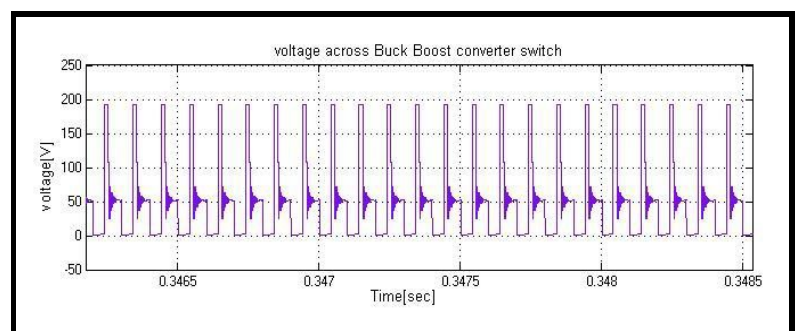

Fig - 14: Voltage across Buck boost converter switch

Fig 13 and Fig 14 are the buck boost converter output power and voltage across the converter switch.

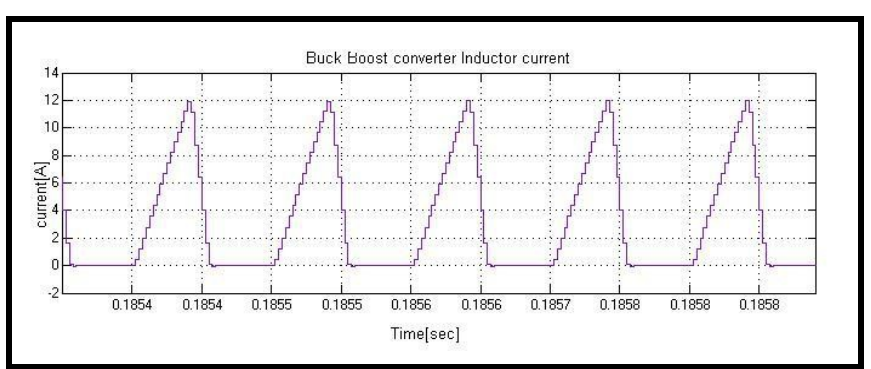

Fig - 15: Buck boost converter inductor current

Fig 15 shows the buck boost converter inductor current which is discontinuous.

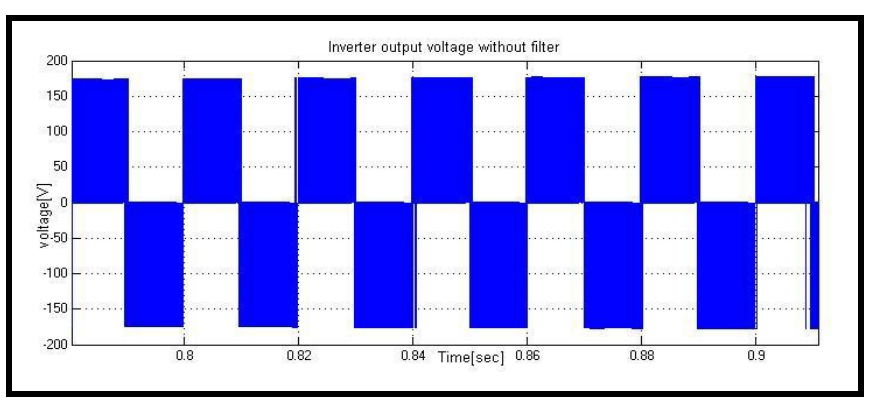

Fig - 16: Inverter output voltage without filter

Buck boost converter output voltage is converted into AC by using Full bridge inverter. Fig 16 is the output voltage of inverter without filter. 


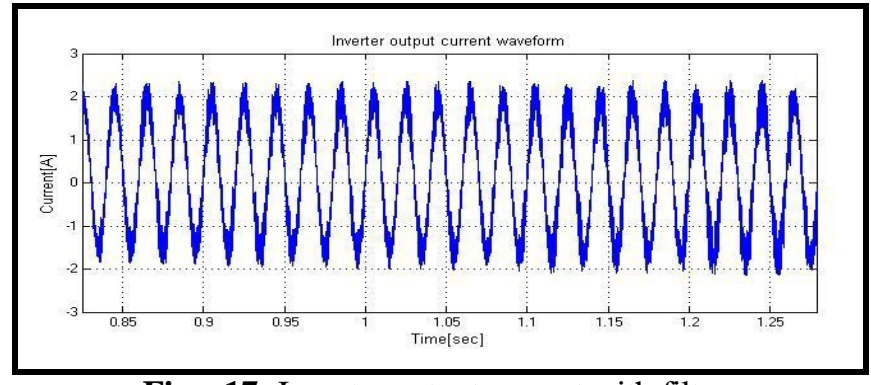

Fig - 17: Inverter output current with filter

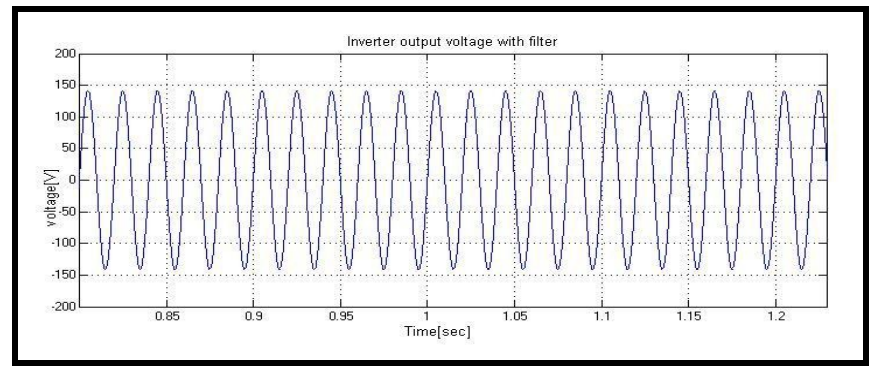

Fig - 18: Inverter output voltage with filter

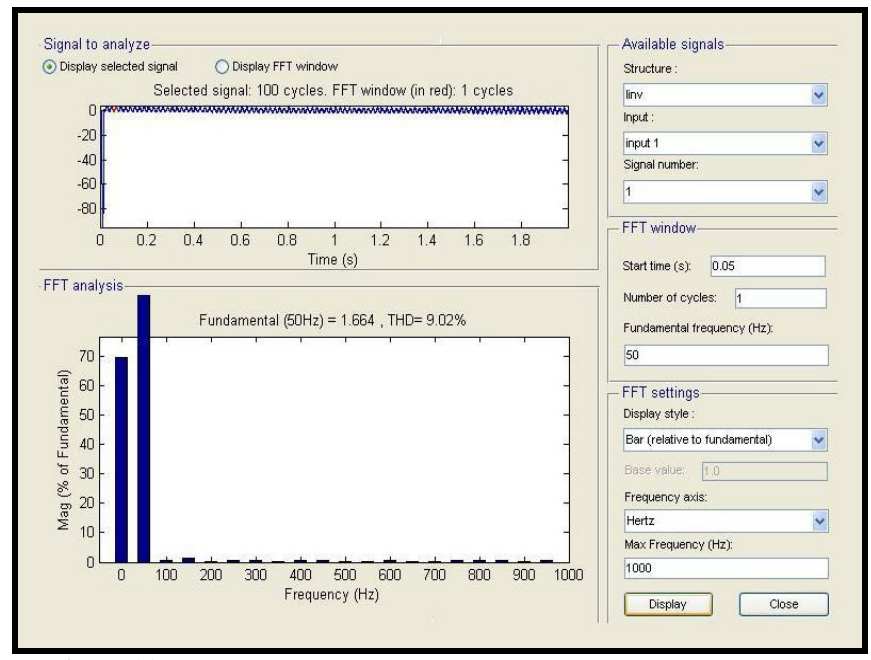

Fig - 19: FFT analysis of inverter output current for one cycle

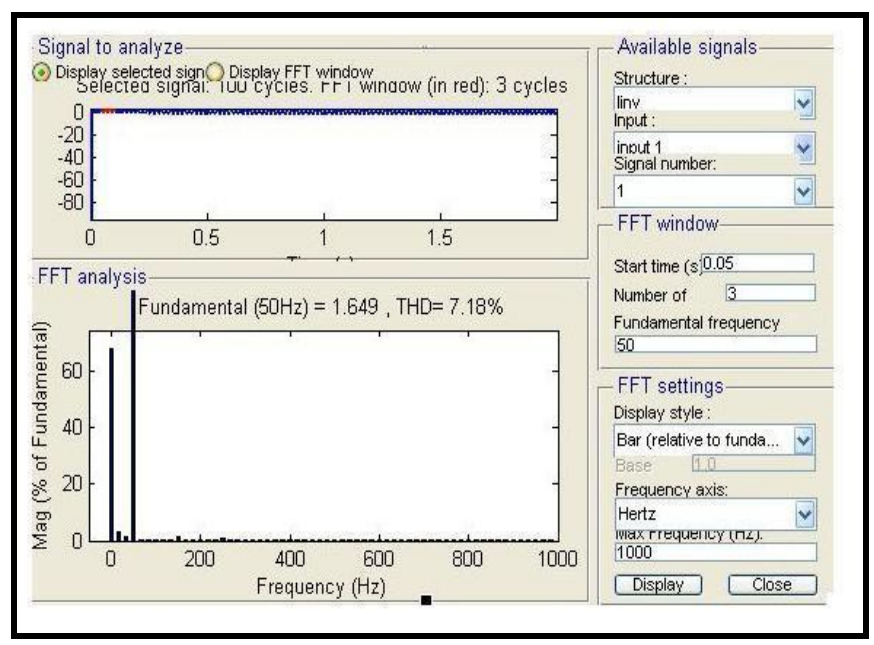

Fig - 20: FFT analysis of inverter output current for three cycles
Fig 17 and Fig 18 shows the filtered output current and voltage of the inverter. The PV module gives the maximum power, voltage and current independent of the load. 32.8 volt photovoltaic voltage is boosted up to 200 volts without any loss of power.

Fig 19 shows the FFT analysis of the output current of inverter for one cycle. Here THD is equal to $9.02 \%$.

Fig 20 shows the FFT analysis of the output current of inverter for three cycles. Here THD is equal to $7.18 \%$.

\section{CONCLUSIONS}

- Photovoltaic current is gradually decreases from short circuit current $5.2 \mathrm{~A}$ to the $5.17 \mathrm{~A}$ and after this it remain constant [Fig. 9].

- Photovoltaic voltage increases from zero to 32.8 volt \& after this value it remains constant [Fig. 10].

- Maximum power output from the photovoltaic module is $169.5 \mathrm{~W}$ which is almost equal to $\mathrm{P}_{\mathrm{mpp}}$ given into the data-sheet [Fig. 11].

- Buck-boost converter output voltage is boosted up from 32.8 volt to 200 volt [Fig. 12].

- Switching losses are significantly reduced due to the allied voltage drop of switching from one state to another in unipolar switching scheme.

- The PV module gives the maximum power, voltage and current independent of the load.

- The power loses incurred at the converter stage is reimbursed at inverter stage.

- Thus the overall efficiency and reliability of the photovoltaic system is improved.

\section{REFERENCES}

[1]. Anuja Namboodiri, Harshal S Wani "Unipolar and bipolar PWM inverter" International journal for Innovation Research in Science \& Technology, volume 1, issue 7, ISSN (Onlin) 2349-6010, pp 237-243 December 2014.

[2]. Bijoyprakash Majhi, "Analysis of Single-Phase SPWM Inverter", National Institute of Technology, Rourkela, May 2012

[3]. Anwarul M Haque, Dr Rahul Dubey "Solar Energy: An Eternal Renewable Power Resource" International Journal of Advanced Research in Electrical, Electronics and Instrumentation Engineering (IJAREEIE) Volume 3, Issue 2, ISSN (Print): 2320-3765 ISSN (Online): 22788875 pp: 7344-7351, February 2014

[4]. Anwarul M Haque, Mohammadshafi V Makwana, Dr Rahul Dubey "Solar Power: An Ever-lasting Nonconventional Energy Resource" published in the proceedings of $2^{\text {nd }}$ National Conference for Innovation in Engineering \&Technology (NCIET-2014), ISBN 978-81925650-0-2, pp 296-300, January-2014.

[5]. Anwarul M Haque, Dr. Rahul Dubey "Emerging Trends in Power Electronics and Power System" published in NCEVT'12 April-2012.

[6]. Claude Morris. "Grid-connected Transformerless Single-phase Photovoltaic Inverters: An Evaluation on DC 
Current Injection and PV Array Voltage Fluctuation" Murdoch University, 2009.

[7]. Anjali Varghese C, Alwarsamy Y, "DC Injection Elimination using Modified Resonant Controllerin Unipolar Switched Transformerless H-Bridge PV Inverter" International Journal of Engineering \& Technology (IJET), Volume 5, Issue 4, ISSN: 0975-4024, pp 3443-3449, September 2013.

[8]. Falinirina F. Rakotomananandro. "Study of Photovoltaic System", The Ohio State University, 2011.

[9]. Dr. B. D. Sharma, "Performance of solar power plants in India" Central Electricity Regulatory Commission, New Delhi, February 2011.

[10]. Anwarul M Haque, Devendra Nagal, Dr Swati Sharma "Power Electronics Interface for PV Systems" International Journal of Research and Scientific Innovation (IJRSI), Volume IV, Issue I, ISSN 2321-2705, pp 268-274, $24^{\text {th }}$ December 2015.

[11]. Anwarul M Haque, Dr. Rahul Dubey "Power Electronics - A Revolutionary Technology for Engineers and Researchers" PEPCCI-2013, ISBN- 978-81-923462-12, January-2013

[12]. Anwarul M Haque, Dr. Swati Sharma, Devendra Nagal, "Simulation of Traditional and Proposed Switched Inductor Buck Boost Converter Connected with Photovoltaic Module by Simulink / Matlab for Analysis, Comparison and Results" International Journal of Scientific \& Engineering Research (IJSER), Volume 6, Issue 11, ISSN 2229-5518, pp 1115-1120, November-2015.

[13]. Jordana Bratt, "Grid connected PV inverters: modeling and simulation" San Diego State University, May 2011.

[14]. Azuan bin alias,"Modeling and simulation of single phase inverter with pwm using matlab/simulink" university Malaysia Pahang, November, 2007.

[15]. A R. Sudharshan Kaarthik, Nayan Kumar Dalei R., Vigneshwaran Rabinarayan Das "Modeling, simulation and implementation of low power photovoltaic energy conversion system", National Institute of Technology Rourkela, May 2010.

[16]. Anwarul M Haque, Mahesh Vadhwaniya, Mohammadshafi V Makwana "Evolution of power Electronics Engineering" published in International Conference 'PEES-2012' organized by Chitkara University, Punjab, India \& school of Engineering \& Built Environment, Glasgow Caledonian University, Scotland, October 2012.

[17]. Anwarul M Haque, Devendra Nagal, Dr. Swati Sharma "Photovoltaic system: A source to Harness Solar Energy" proceedings of 'International Conference on Emerging Trends in Scientific Research (ICETSR-2015)', published by Institute of Research and Development (IRD-India) ISBN 978-2-642-24819-9, pp 73-78, 17-18 December 2015. [18]. Malki sihem, "Maximum power point tracking for photovoltaic system" M'hamed Bougara Boumerdes university, 2011.

[19]. Omar Abdel-Rahim, Mohamed Orabi, Mahrous E. Ahmed. "High Gain Single - Stage Inverter for PV AC Modules", IEEE Transactions, 2011.

[20]. Bindu B."Design \& Development of an efficient inverter System for Single-Phase Non-Conventional Energy
System" 'International Journal of Innovative Research in Electrical, Electronics, Instrumentation and Control Engineering', Vol. 2, Issue 3, ISSN (Online) 2321 - 2004, ISSN (Print) 2321 - 5526, pp1197-1202, March 2014.

[21]. Sudha Bhutada, Dr. S.R. Nigam, "Single Phase PV Inverter Applying a Dual Boost Technology", International Journal of Scientific Engineering and Technology (IJSET)' Volume No.4 Issue No.6, ISSN: 2277-1581, pp: 356-360, $1^{\text {st }}$ June 2015.

[22]. S. Yogesh, K. Guna prasad, S. Ramesh, R. Ramesh, "Five-Level Full-Bridge Single-Phase Grid Connected Converter for Renewable Distributed Systems", International Journal of Advanced Research in Electrical, Electronics and Instrumentation Engineering (IJAREEIE)', Vol. 3, Issue 8, ISSN (Print): 2320 - 3765, ISSN (Online): 2278 - 8875, pp 11327-11333, August 2014.

[23]. Biswajeet Panda, Ashirbad Sahoo, "Study of Soft Switching Boost Converter Using an Auxiliary Resonant Circuit" Thesis Submitted in Department of Electrical Engineering, National Institute Of Technology Rourkela, May-2012.

[24]. Bhavesh Dave, "Design \& Simulation of Buck-Boost Converter Modulation Technique for Solar Application", Journal of Information, Knowledge and Research in Electrical Engineering (JIKREE), Volume - 02, Issue - 02, ISSN: 0975 - 6736, Pp 336-341, Nov. 2012-Oct. 2013.

[25]. M. Nehru, K. Rajani, "Grid Integration of Renewable Energy Source Using Single - Phase Bidirectional Multilevel Inverter DG Applications", International Journal of Informative \& Futuristic Research, Volume 2, Issue,1, ISSN (Online): 2347-1697, pp 231-243,September 2014.

[26]. V.Abinaya, B.Prabakaran, R.B.Selvakumar, "An Improved Transformer-less Inverter for Grid-Connected Photovoltaic Power Systems", International Journal of Engineering and Innovative Technology (IJEIT), Volume 2, Issue 12, ISSN: 2277-3754, pp 5-9, June 2013.

\section{BIOGRAPHIES}

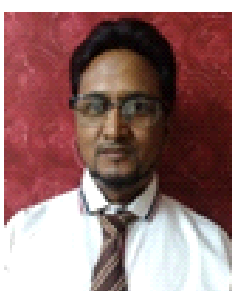

Prof Anwarul M. Haque was born in India, Bihar, in 1967. He received his B.E (Power Electronics) in 1989 and M. Tech (Electrical - Power System) in 2012 respectively from Saurashtra University and Manav Bharti University. Currently he is working with VGEC, Ahmedabad, Gujarat and pursuing his $\mathrm{PhD}$ (Electrical Engineering) from Jodhpur National University, Jodhpur, Rajasthan since July 2012.

He was a Member of Board of Studies in Power Electronics Engineering, Saurashtra University for two years during 2009-2011. He has published 8 research papers in national conference, International Conference \& Journals. 5 more publications are under review process of various journals. His research interest include Photovoltaic System, Distributed Generation, Power System \& Artificial Intelligence applied to Power Electronics.

Prof. Haque is a life member of Indian society of Technical Education (ISTE), Life fellow member of the society of power engineers SPE-(India) and Life associate member of 
Institute of Electronics and Telecommunication Engineers (IETE).

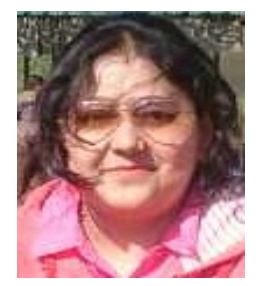

Dr. Swati Sharma was born in Jodhpur, Rajasthan, India on 15th August 1985. She received her BE Degree from University of Rajasthan, Jaipur in 2007 and ME Electrical (Control System) from J. N. V. University, Jodhpur, Rajasthan in 2010. She completed her PhD form J. N. V. University, Jodhpur in 2013. Currently she is working as an Associate Prof. (Reader) in the Department of Electrical Engineering as well as Deputy Chairperson of the Department of Jodhpur National University. She has published 65 research papers in various International Conferences / Journals and National Conferences including 5 papers in IEEE. 6 more publications are under review process of various journals. She was Editorial Board Member of International Journal of Advance Research in Science and Engineering. She has received best paper award for "FCM Based Algorithm for QRS Detection in Single Lead ECG Using Derivative and Combined Entropy", at 2nd International Conference on Biomedical Engineering and Assistive Technologies (BEATS 2012), at NIT Jalandhar (Punjab) in Dec 2012, \& "Virtual Reality in Biomedical", International Conference on Electrical Engineering and Computer Science (ICEECS) held at Dehradun on 9th Sep 2012. Her research interest include AC/DC Machines, Biomedical Instrumentation, Pattern Recognition, Artificial Intelligence and Expert System, Computer Added Design (CAD), Neural Networks and Control-System.

Dr. Sharma is an Associate Member of INSTITUTE OF ENGINEERS INDIA, Member of INTERNATIONAL ASSOCIATION OF ENGINEERS (HONGKONG), Senior Member of INSTITUTE OF RESEARCH ENGINEERS AND DOCTORS and Life Member of INDIAN SOCIETY OF TECHNICAL EDUCATION (ISTE).

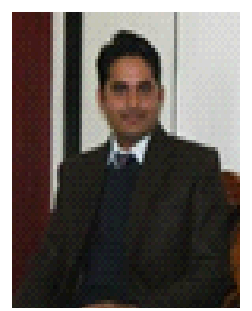

Devendra Nagal was born in Jodhpur, Rajasthan, India on 2nd March 1987. He received his BE Degree from University of Rajasthan, Jaipur in 2009 and ME Electrical (Control System) from M. B. M. College, Jodhpur in 2013. Presently he is working as an Assistant Professor at JNU, Jodhpur and pursuing his $\mathrm{PhD}$ in Electrical Engineering. He has published 42 research papers in various International Journals, International Conferences and National Conferences. He has received best paper award for "FCM Based Algorithm for QRS Detection in Single Lead ECG Using Derivative and Combined Entropy", at 2nd International Conference on Biomedical Engineering and Assistive Technologies (BEATS 2012), at NIT Jalandhar (Punjab), Dec 2012 and best presentation award at the International Conference on Electrical Engineering and Computer Science (ICEECS) held at Dehradun on 9th September, 2012.
Prof. Nagal is a Member of INSTITUTE OF ENGINEERS (INDIA) and INTERNATIONAL ASSOCIATION OF ENGINEERS (HONGKONG). 